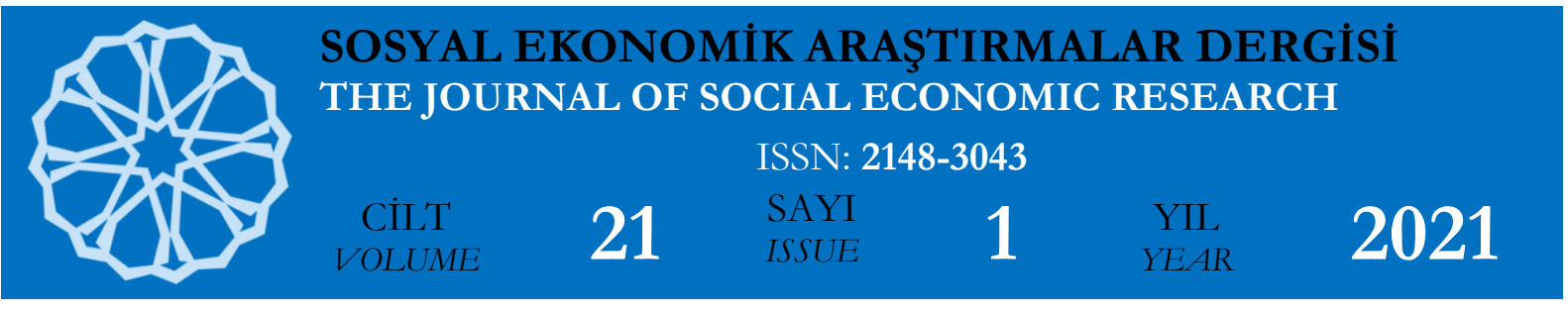

\title{
TEDARİK ZİNCİRİ ENTEGRASYONU, OPERASYONEL ÇEVİKLIKK VE KİTLESEL KİŞİSELLEŞTİRME YETENEĞİ: İMALAT SEKTÖRÜNDE AMPİRİK BİR ARAŞTIRMA
}

\author{
SUPPLY CHAIN INTEGRATION, OPERATIONAL AGILITY AND MASS \\ CUSTOMIZATION CAPABILITY: AN EMPIRICAL RESEARCH IN THE \\ MANUFACTURING INDUSTRY
}

Sibel YILDIZ ÇANKAYAa, Yeşim CAN SAĞLAM ${ }^{\mathrm{b}}$

\begin{abstract}
aDr. Öğr. Üyesi, Bolu Abant İzzet Baysal Üniversitesi, İșletme Bölümü, Bolu, Türkiye.

ORCID: 0000-0003-4942-

1415.

E-posta:

sibelyildiz@ibu.edu.tr

bArș. Gör. Gebze Teknik

Üniversitesi, İşletme Bölümü,

Kocaeli, Türkiye.

ORCID: 0000-0003-0528

6135

E-posta:

yesimcan@gtu.edu.tr
\end{abstract}

Sorumlu Yazar:

Sibel Yıldız Çankaya

Makale Türü

Araştırma Makalesi

Makale Geliş Tarihi

30.07.2020

Makale Kabul Tarihi 08.04.2021

\section{ÖZ}

Amaç - Bu çalıșmada tedarik zinciri entegrasyonunun, operasyonel çeviklik ve kitlesel kişiselleştirme yeteneği üzerindeki etkisinin incelenmesi amaçlanmaktadır.

Yöntem - Araştırmada Türkiye'de faaliyet gösteren imalat ișletmeleri arasından kolayda örnekleme metodu ile seçilmiş 83 işletme üzerinde anket çalışması gerçekleştirilmiştir. Araştırma amacına ulaşmak ve bu doğrultuda geliştirilen hipotezleri test etmek için kısmi en küçük kareler yapısal eşitlik modeli (PLS-YEM) tercih edilmiştir.

Bulgular - 83 işletme üzerinde yapılan analizlerle tedarik zinciri entegrasyonunun üç boyutundan sadece iç entegrasyonun operasyonel çeviklik ile pozitif ilişkili olduğu ayrıca müşteri ve tedarikçi entegrasyonunun kitlesel kişiselleştirme yeteneği ile pozitif ilişskili olduğu tespit edilmiştir.

Sonuç - Araştırma sonuçlarına göre, tedarik zinciri entegrasyonunun bazı boyutlarının operasyonel çevikliğin ve kitlesel kișiselleștirme yeteneğinin gelișmesini olumlu bir șekilde etkileyeceği söylenebilir.

Anahtar Kelimeler: Tedarik zinciri yönetimi, Tedarik zinciri entegrasyonu, Operasyonel çeviklik, Kitlesel kişiselleştirme yeteneği, Yapısal eşitlik modellemesi JEL Kodları: M11

\section{ABSTRACT}

Purpose -In this study, it is aimed to examine the effect of supply chain integration on operational agility and mass customization capability.

Methodology - In this study, the survey was conducted with 83 firms selected by convenience sampling method from among manufacturing firms in Turkey. To achieve aim of the research and test the hypotheses developed in this direction, partial least squares - structural equation modelling (PLS-SEM) was utilized.

Findings - As a result of the research conducted on eighty three firms, this paper determined that only internal integration from three dimensions of supply chain integration is positively associated with operational agility and customer and supplier integration is positively associated with mass customization capability.

Conclusions - According to research results, it can be said that some dimensions of supply chain integration will positively affect the development of operational agility and mass customization ability.

Keywords: Supply chain management, Supply chain integration, Operational agility, Mass customization capability

JEL Codes: M11 


\section{GİRİŞ}

Tedarik zinciri yönetimi (TZY), tedarikçilerden nihai müşteriye doğru hareket eden hammaddeler, bileşenler ve nihai ürünler ile ilgili eylemlerin planlanmasını ve kontrolünü içeren faaliyetler bütünüdür (Stonebraker \& Liao, 2004, s. 1039). TZY, 21. yüzyılın küresel pazarında işletmeler arasında rekabet üstünlüğü sağlamada kilit role sahiptir ve nihai tüketiciye değer yaratan tüm farklı süreçlerin yönetimini kapsamaktadır. Tedarik zinciri entegrasyonu (TZE) ise bir işletmenin, tedarik zinciri ortaklarıly stratejik olarak iş birliği yapma ve hem işletme içi hem de işletmeler arası süreçleri iş birliği içinde yönetme derecesi anlamına gelmektedir. Günümüzde işletmeler, TZY performansını arttırmak için tedarik zinciri üyeleriyle sıkı ilişkiler geliştirmeye çalışmakta ve karşılıklı fayda sağlayacak bilgi akışını oluşturmanın yollarını aramaktadırlar. Bu yüzden, işletmelerin rekabetçi bir ortamda zorluklarla başa çıkabilmeleri için, TZE'yi uygulamaları zorunlu bir hale gelmiştir (Yu, Huo, \& Zhang, 2021, s. 464).

İşletmelere rekabet avantajı sağlayacak bir başka kavram ise kitlesel kişiselleştirmedir. Günümüzde işletmelerin, sürdürülebilir rekabet avantajı elde edebilmek için sürekli değişen müşteri istek ve ihtiyaçlarına etkili ve verimli bir şekilde cevap verebilmeleri gerekmektedir. Bir işletme felsefesi ve hedefi haline gelen bu amacın gerçekleştirilmesinde kitlesel kişiselleştirmenin önemi büyüktür. Kitlesel kişiselleştirme kavramı, değişen ürün taleplerini karşılamak için ürün ve hizmet farklılaştırması yoluyla yenilikler yaratarak daha geniş müşteri kitlesine hizmet etme yeteneği olarak tanımlanmaktadır. İşletmenin, herhangi bir müşterisinin isteğine uygun ürün üretmesi kişiye öz̧el ̈̈retim kavramın1, her bir müşterisinin isteğine göre ürün sunması ise kitlesel kişiselleşstirme kavramını nitelemektedir (Yüksel, 1999, s. 213). Yoğunlaşan rekabetle birlikte müşteri taleplerinin artan heterojenliği, kitlesel kişiselleștirme yeteneğinin geliştirilmesini işletmeler için bir zorunluluk haline getirmiştir (Sandrin, Trentin, \& Forza, 2018, s. 335). Bununla birlikte araştırmalar, kitlesel kişiselleştirmenin çoğu işletme tarafindan başarılı bir şekilde uygulanamadığını belirtmektedirler. $\mathrm{Bu}$ başarısızlığın nedeninin büyük bir kısm1, kitlesel kişiselleştirmenin öncüllerinin yeteri kadar anlaşılmamasından kaynaklanmaktadır. Etkili bir kitlesel kişiselleştirme iki ana yetkinliğe bağlıdır. Bunlar; talep tarafindan müşteri ihtiyaçlarını doğru bir şekilde anlama yeteneği ve arz tarafından ürünlerin zamanında üretimi için doğru miktarda bileşen temin etme yeteneğidir. Kısacası tedarik zincirini etkin bir şekilde yönetmek, kitlesel kişiselleştirme için kritik öneme sahiptir. Kitlesel kişiselleştirmenin başarılmasında tedarik zinciri yönetiminin önemli bir rol oynadığına dair artan bir kabul olsa da bu konudaki çalışmaların çoğu işletmelerin müşterilerle etkileşimine ya da entegrasyonuna odaklanmakta, tedarikçiler ve iç fonksiyonlar arasındaki entegrasyon ise genellikle ihmal edilmektedir. Oysa, tedarikçiden gelen parçalardaki eksiklikler, kalite sorunları ve uzun teslim süreleri bir işletmenin kitlesel kişiselleştirme yeteneğine zarar vermektedir. Benzer şekilde, kitlesel kişiselleştirmeyle birlikte artan ürün çeşitliliği, eğer işletmenin iç fonksiyonları iyi entegre olmamıssa çizelgelemede ve koordinasyonda problemlerin ortaya çıkmasına neden olacaktır (Liu, Zhang, \& Guo, 2018, s. 609-611). Sonuç olarak, kitlesel kişiselleştirme, işletmenin iş süreçlerinde kaynaklarını ve yeteneklerini hem iç hem de dış paydaşlarıyla koordinasyonlu bir şekilde kullanmasını gerektirmektedir (Zhang, Zhao, \& Qi, 2014, s. 145).

Kitlesel kişiselleştirme için gerekli olan bir diğer kavram ise çevikliktir. Çeviklik; operasyonel çeviklik, iş ortaklığı çevikliği ve müşteri çevikliği olmak üzere genelde üç boyutta ele alınmaktadır (Akhtar, Khan, Tarba, \& Jayawickrama, 2018, s. 308; Fremdt, Beck, \& Weber, 2013, s. 1026). Bu çalışmada sadece operasyonel çeviklik üzerinde durulacaktır. Operasyonel çeviklik, işletmenin belirsizliklere ve değişimlere hızlı bir şekilde yanıt verebilme yeteneğini ifade etmektedir. Operasyonel çevikliğe sahip bir işletme, pazar değişikliklerine uyum sağlayabilecek, pazar firsatlarını hızlı bir şekilde değerlendirebilecek ve gerektiğinde işletme içindeki süreçleri yeniden tasarlayabilecektir. Tüm bu faktörler, kişiselleştirilmiş ürünlerin teslim süresinin kısalmasına neden olacaktır. Literatüre baktı̆ıımıda birçok kavramsal çalışma kitlesel kişiselleştirmeyi başarmak için çevikliğin önemine değinmektedir (Da Silveira, Borenstein, \& Fogliatto, 2001, s. 5). Fakat bu iki kavram arasındaki ilişkiyi ampirik olarak inceleyen az sayıda çalşsma olduğu görülmektedir. Burada diğer bir önemli konu ise operasyonel çevikliğin nasıl artırılacağıdır. Çeviklik için dışsal ve içsel bilgilerin hızlı ve doğru bir şekilde elde edilmesi gerekmektedir. Eski bilgilerin güncellenmesi, süreçlerin yeniden yapılandırılmasına ve talepteki değişikliklere hızlı cevap verme yeteneğinin gelişmesine katkıda bulunacaktır. Kısacası, etkili bir TZE ile operasyonel çevikliğin gelişebileceği düşünülmektedir (Jajja, Chatha, \& Farooq, 2018, s. 123). Son yıllarda yürütülen çalışmalar sayesinde, operasyonel çeviklikle ilgili bilgiler artsa da operasyonel çevikliğin nasıl elde edileceğine ilişkin temel sorun henüz tamamen çözümlenmemiştir (Huang, Pan, \& Ouyang, 2014, s. 462-463). Dolayısıyla operasyonel çevikliği arttıracak faktörlerin saptanmasına ve bu faktörler ile operasyonel çeviklik arasındaki ilişkilerin incelenmesine ihtiyaç vardır. Buradan hareketle, bu çalışma TZE, 
kitlesel kişiselleştirme yeteneği ve operasyonel çeviklik arasındaki ilişkileri ampirik olarak incelemeyi amaçlamaktadır. Türkiye'de faaliyette bulunan işletmeler üzerinde kısmi en küçük kareler yapısal eşitlik analizi (PLS-YEM) ile bu değişkenler arasındaki ilişkiler test edilmiştir. Çalışmanın bölümleri şu şekilde organize edilmiştir: Girişin ardından 2. bölümde kavramsal çerçeve ve araştırma hipotezleri hakkında bilgi sunulmaktadır. 3. bölümde araştırma metodolojisine yer verilmektedir. 4. bölümde ise sonuçlar ve gelecek araştırmalar için öneriler tartısılmaktadır.

\section{LİTERATÜR TARAMASI}

\subsection{Kavramsal Çerçeve}

\subsubsection{Tedarik Zinciri Entegrasyonu}

Entegrasyona odaklanmak, tedarik zincirinin yapı taşlarından biri olarak görülmektedir (Stonebraker \& Liao, 2004, s. 1039). Tedarik zinciri entegrasyonu, bir işletmedeki tüm faaliyetler ile işletmenin tedarikçilerinin, müşterilerinin ve diğer tedarik zinciri ortaklarının fonksiyonel faaliyetlerinin birbirleriyle bağlantılı olmasını ifade etmektedir (Sundram, Bahrin, Munir, \& Zolait, 2018, s. 754). Literatürde, tedarik zinciri entegrasyonu için kabul görmüş tek bir tanım bulunmamaktadır. Romano (2003) TZE’yi, örgüt içi ve örgüt dış1 sınırların üstesinden gelmek için tedarik ağındaki iş süreçlerini destekleyen bir mekanizma olarak tanımlamıştır. Cagliano vd. (2006), TZE'nin koordinasyon mekanizmalarıyla ilişkili olduğunu ve iş süreçlerinin hem örgüt içinde hem de örgüt dışında birbirine bağlanması anlamına geldiğini belirtmişlerdir. Bagchi vd. (2005) ise TZE'yi stratejik ve taktiksel alanlarda tedarik zinciri üyeleri arasındaki kapsamlı iş birliği olarak açıklamışlardır. TZE ile ilgili olarak farklı yazarlar farklı noktalara değindikleri için bu kavramın yapısında hangi bileşenlerin bulunduğu konusunda fikir birliğine varmak zorlaşmaktadır. Bazı yazarlar koordinasyon üzerinde dururken bazıları iş birliğine vurgu yapmakta, bir diğer kesim ise bilgi paylaşımını ön plana çıkarmaktadır. Alfalla-Luque vd. (2013)'nin yaptığ literatür analizinde, TZE'nin yapısıyla ilgili olarak üç noktaya dikkat çekilmiştir: Bilgi paylaşımı, koordinasyon-kaynak paylaşımı ve örgütsel ilişki. Çalışmada, bu üç bileşenin hem kurum içi hem kurum dışı (tedarikçi-müşteri) değerlendirilmesi gerektiği vurgulanmıştır. $\mathrm{Bu}$ bileşenler, bir işletmenin entegrasyon düzeyini iyileştirmek için üzerinde durulması gereken noktaları tanımlamaktadır. Yukarıdaki ifadelerden de anlaşılacağı üzere TZE, sadece bir süreç ve teknikten ibaret değildir; aynı zamanda insan ve örgütsel davranış bileşenlerini de bünyesinde barındırmaktadır. Bu nedenle, işletmeler arasındaki resmi ve gayri resmi iletişim, iş birliği ve anlaşmalar, TZE'nin başarılı olması için vazgeçilmez unsurlardır (Alfalla-Luque, Medina-Lopez, \& Dey, 2013, s. 812).

Mevcut literatür, tedarik zinciri entegrasyonunu, tedarikçi entegrasyonu, müşteri entegrasyonu ve içsel entegrasyon olmak üzere üç temel boyutla ele almaktadır (Flynn, Huo, \& Zhao, 2010, s. 59; Schoenherr \& Swink, 2012, s. 100; Munir, Jajja, Chatha, \& Farooq, 2020, s. 3). Bazı kaynaklar ise TZE'yi, iç ve dış entegrasyon olarak sınıflandırmaktadır. Genellikle müşteri ve tedarikçi entegrasyonu olarak bilinen dış entegrasyon, bir işletmenin kilit tedarikçileri ve müşterileri ile ortak değer yaratmak için kurumlar arası stratejileri, uygulamaları ve süreçleri senkronize ve iş birliğine dayalı bir şekilde yapılandırma derecesini ifade etmektedir (Flynn, Huo, \& Zhao, 2010, s. 59; Munir, Jajja, Chatha, \& Farooq, 2020, s. 3). Müşteri entegrasyonu, kilit müşterilerle yakın ilişkileri ve bilgi paylaşımını kapsamaktadır. Bu entegrasyon, işletmeye pazarın beklentilerini karşılamada ve firsatlanı değerlendirmede stratejik bakış açısı geliştirme imkânı sunmaktadır. Böylece işletme, müşteri istek ve ihtiyaçlarına daha etkili ve verimli bir şekilde cevap verebilir hale gelecektir (Munir, Jajja, Chatha, \& Farooq, 2020, s. 3). Tedarikçi entegrasyonu ise stratejik öneme sahip tedarikçilerle koordinasyonu ve bilgi paylaşımını ifade etmektedir. Bu entegrasyon, işletmeye tedarikçilerinin yetenekleri, iş süreçleri, imkânları ve sınırları hakkında sağlam bilgiler sunmakla kalmayıp, aynı zamanda etkili ve verimli süreç ve operasyon yönetimi sağlamaktadır (Schoenherr \& Swink, 2012, s. 100).

Tedarikçi ve müşteri entegrasyonu, doğru talep tahmini yapmayı ve kaynakları verimli kullanmayı mümkün kılmaktadır. Bu entegrasyonlar aynı zamanda kırbaç etkisine neden olan bilgi aksaklıklarını da azaltmaya yardımcı olmaktadır. Tedarik zinciri üyeleriyle birlikte geliştirilen tam zamanında üretim ve tedarikçi tarafından yönetilen stok gibi uygulamalarla kırbaç etkileri azaltılabilir ve ortak karar verilerek arz ve talepteki değişikliklere hızlı cevap verme yeteneği geliştirilebilir (Munir, Jajja, Chatha, \& Farooq, 2020, s. 5).

Dış entegrasyondan farklı bir kavram olan iç entegrasyon ise işletmenin üretim içerisindeki faaliyetlere odaklanmasını ifade etmektedir. Fonksiyonlar arası iş birliği ve paydaşlarla senkronize edilmiş bilgi paylaşımı, iç entegrasyonun önemli mihenk taşlarındandır (Munir, Jajja, Chatha, \& Farooq, 2020, s. 3). İç entegrasyon, 
bir işletme içindeki farklı departmanların ve fonksiyonel alanların entegre bir sürecin parçası olarak çalışması gerektiğini ifade etmektedir. Bu entegrasyon ile organizasyon içerisinde ortak bir hedefe odaklanılması ve tüm çabaların bu doğrultuda koordine edilmesi, kaynakların işletme için kullanımını arttırmakta ve müşteri ihtiyaçlarına daha hızlı yanıt verilmesini sağlamaktadır (Jajja, Chatha, \& Farooq, 2018, s. 123).

\subsubsection{Kitlesel Kişiselleştirme Yeteneği}

İşetmelerin rekabet avantajı kazanabilmeleri için sadece fiyat, kalite, teslim tarihi ve sunulan hizmet gibi faktörler üzerinde yoğunlaşmaları yeterli olmamaktadır. İşletmelerden müşterilerini memnun etmeleri için yukarıda sayılan bu faktörlerin yanında, ürün ve hizmetlerini özelleștirmeleri de beklenmektedir. Bu noktada devreye giren kitlesel kişiselleştirme yeteneği, bir işletmenin maliyetten, teslimattan ve ürün kalitesinden ödün vermeden, her müşterinin kendine özgü ihtiyaçlarını karşlayan, özelleştirilmiş ürünler ve hizmetler sunma yeteneğini ifade etmektedir (Sandrin, Trentin, \& Forza, 2018, s. 335; Tu, Vonderembse, \& RaguNathan, 2001, s. 202). Bu yetenek, yüksek hacimli kişiselleştirme, kişiselleştirmede maliyet verimliliği, kişiselleştirmede yanıt süresi ve kişiselleştirmede kalite olmak üzere dört bileşenden oluşmaktadır. Yüksek hacimli kişiselleştirme, bireysel müşterilerin taleplerini büyük partili ortak parça üretiminde bir araya getirme yeteneği anlamına gelmektedir. Kişiselleştirmede maliyet verimliliği, özelleştirilmiş ürünlerin, seri üretimdeki fiyatlara benzer bir fiyatla sunulabilmesi yeteneğidir. Üçüncü bileşen olan kişiselleştirmede yanıt süresi, kişiselleştirilmiş ürünlerin tesliminde, toplam teslim süresini azaltma becerisini nitelemektedir. Son bileşen olarak kişiselleştirme kalitesi ise her özelleştirilmiş ürünün kalite düzeyini yönetme ve bu kalitenin sağlanacağını garanti etme yeteneğine vurgu yapmaktadır (Zhang, Zhao, \& Qi, 2014, s. 146).

İşletmelerin kitlesel kişiselleştirme yeteneğini geliştirmek istemelerindeki amaç, pazarın sürekli değişen ve çeşitlenen ihtiyaçları karşısında etkili ve verimli bir şekilde denge oluşturmaktır. Belirtilen amaca ulaşabilmek için önemli olan nokta işletmenin sunduğu ürünlerin müşterinin istediği özelliklerde özelleştirilebilir olmasını sağlamaktır. Bu durum, ürün tasarımı sırasında güçlü bir müşteri odağı gerektirmektedir (Liu \& Deitz, 2011, s. 671-672). Yani bir işletmenin kitlesel kişiselleştirme yeteneği elde edebilmesi için, müşteri ihtiyaçlarını doğru bir şekilde değerlendirebilmesi, bu anlayışı ürün tasarımlarına yerleştirebilmesi ve bireysel ürün konfigürasyonlarının zamanında üretimi ve teslimatı için uygun ve doğru malzemeleri tedarik edebilmesi gerekmektedir. Kısacası, işletmenin kitlesel kişiselleştirme yaklaşımını başarılı bir şekilde uygulayabilmesi, tedarik zinciri ilişkilerini etkili bir şekilde yönetmesine bağlıdır (Liu \& Deitz, 2011, s. 669).

\subsubsection{Operasyonel Çeviklik}

Aşırı rekabet, küreselleşme ve teknolojik gelişmeler, iş ortamının karmaşık bir hal almasına sebep olmaktadır. Böyle bir ortamda tehditleri ve firsatları kolayca algilama ve bunlara cevap verebilme yeteneği, işletmelere önemli bir rekabet avantajı kazandıracaktır. Bu nedenle işletmelerin çevik bir yapıya sahip olmaları, başarı elde edebilmeleri ve hatta hayatta kalmaları için oldukça önemlidir (Huang, Ouyang, Pan, \& Chou, 2012, s. 294). Çeviklik, bir işletmenin değişen ortamlara uyum sağlama yeteneğini ifade etmektedir (Fremdt, Beck, \& Weber, 2013, s. 1026). Literatürde çeviklik; müşteri, iş ortaklığ1 ve operasyonel çeviklik olmak üzere genelde üç boyutta ele alınmaktadır (Akhtar, Khan, Tarba, \& Jayawickrama, 2018, s. 308; Fremdt, Beck, \& Weber, 2013, s. 1026). Müşteri çevikliği, bir işletmenin pazar firsatlarını araştırırken ve değerlendirirken müşterileriyle iş birliği yapmasını ifade etmektedir. Başka bir deyişle müşteri çevikliği, müşterilerden pazar bilgisi elde edilerek pazar koşullarına uygun rekabetçi eylemlerin oluşturulmasıdır. İş ortaklığı çevikliği, bir işletmenin sahip olmadığ yeteneklere ve bilgilere erişmesi gerektiğinde sanal, genişletilmiş veya stratejik ortaklıklar ağı kurabilme yeteneğidir. Bu sayede işletmeler, ilgili kaynakları ve varlıkları entegre ederek firsatları keşfedebilir ve kullanabilirler (Liu, Chan, \& Yang, 2018, s. 102). Operasyonel çeviklik ise işletmenin yenilik ve rekabetçi eylem firsatlarını değerlendirirken gerekli hıza, doğruluğa ve maliyet verimliliğine ulaşabilmesini sağlayan yetenekler olarak tanımlanmaktadır (Huang, Ouyang, Pan, \& Chou, 2012, s. 294). Bu tanımda yazarlar üç noktaya dikkat çekmişlerdir: Hızlı yanıt verme, doğru eylemleri gerçekleştirme ve maliyet verimliliğine ulaşabilme. Bir başka tanımda operasyonel çeviklik, işletmenin kaynaklarını ve iş süreçlerini etkili, verimli ve hızlı bir şekilde yeniden yapılandırarak değişiklikleri algılama ve bunlara tepki verebilme yeteneği biçiminde açıklanmıştır (Beck, Pahlke, \& Vykoukal, 2016, s. 12). Operasyonel çeviklikle ilgili farklı tanımlar olmakla beraber, bu tanımlarda özellikle hız faktörünün üzerinde durulduğu görülmektedir. Çevikliğin sağlanabilmesi için hız faktörü önemli bir bileşen olmakla beraber, tek başına yeterli değildir. 
Literatürde, çevikliğin sağlanabilmesi için dört temel bileşenin gerekliliği vurgulanmaktadır. Bunlar; cevap verebilirlik, yetkinlik, esneklik ve hızdır. Cevap verebilirlik, değişiklikleri belirleyebilme ve bunlara yanıt verebilme becerisi olarak tanımlanmaktadır. Yetkinlik, işletme hedeflerini etkili, verimli ve güvenilir bir şekilde gerçekleştirme kabiliyeti olarak ifade edilmektedir. Esneklik, değişen koşullara uyum yeteneğini öne çıkartmakta ve işletmenin amaca ulaşabilmesi için farklı süreç ve alternatifleri kullanabilme becerisinin altını çizmektedir. Hız, mümkün olan en kısa sürede görevleri ve operasyonları gerçekleştirme yeteneğini belirtmektedir. Yukarıdaki tanımlardan çevikliğin cevap verme yeteneği ile hızlı davranabilme yeteneği arasında güçlü bir ilişki olduğu görülmektedir. Araştırmacılar, cevap verebilirliğin işletmelerin değişikliklere nasıl tepki verecekleri konusunda karar alma sürecini, hızlı davranmanın ise verilen kararın uygulamaya geçirilme sürecini kapsadığını vurgulamaktadırlar (Akkaya \& Tabak, 2018, s. 187-189).

\subsection{Araştırma Hipotezleri}

Bu çalışma, tedarik zinciri entegrasyonunu sadece içsel bakış açısıyla incelemekle kalmayıp, aynı zamanda dışsal bir perspektifle de ele almaktadır. Bundan dolayı TZE, literatürde kabul edildiği gibi müşteri, tedarikçi ve iç entegrasyon şeklinde üç temel alt boyut ile incelenecektir. Tedarik zinciri entegrasyonu ile operasyonel çeviklik ve kitlesel kişiselleştirme yeteneği arasındaki ilişkileri anlatan araştırma modeli Şekil 1'de sunulmaktadir.

Şekil 1. Araştırma Modeli

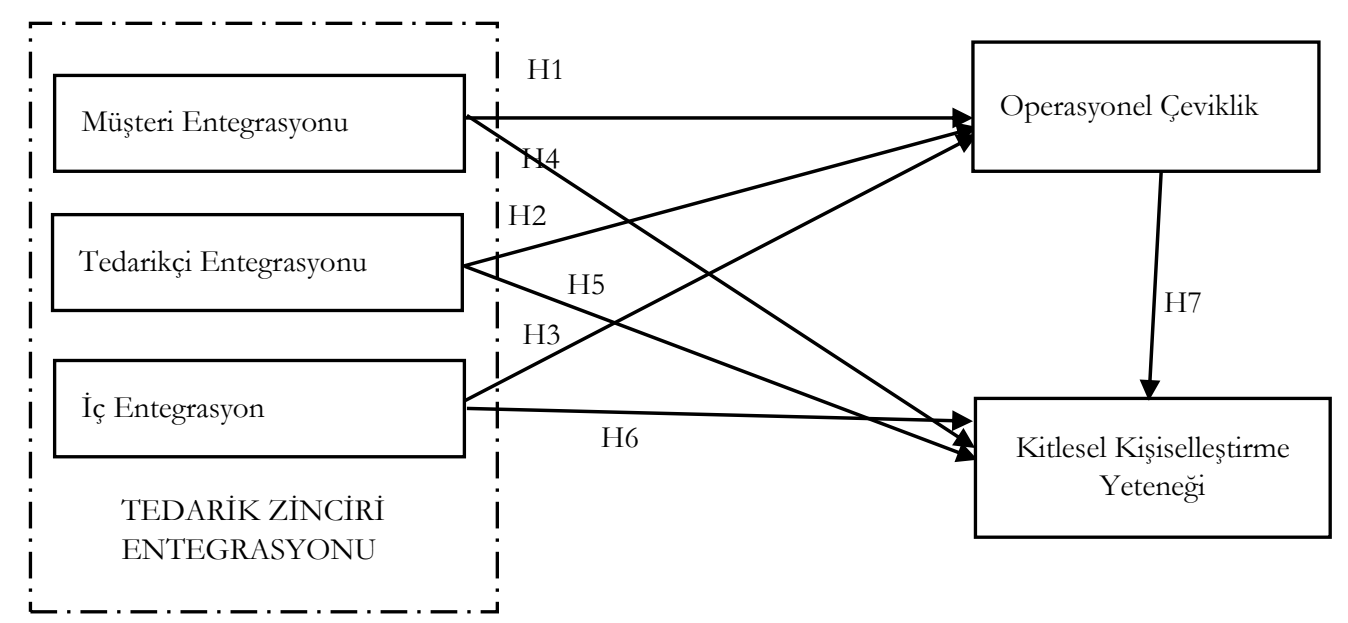

\subsubsection{Tedarik Zinciri Entegrasyonunun Operasyonel Çeviklik Üzerindeki Etkisi}

Tedarik zinciri entegrasyonu ile işletmelerin daha çevik bir yapıya kavuşacağı düşünülmektedir. Örneğin, müşteri ve tedarikçi entegrasyonu yoluyla pazarda yaşanan değişiklikler daha yakından takip edilip uygun stratejiler geliştirilebilir. Benzer şekilde iç entegrasyonun, müşterilerin gereksinimlerini karşılamak için fonksiyonel engelleri ortadan kaldırması ve fonksiyonlar arasında iş birliğini sağlaması nedeniyle performansı artırması beklenmektedir (Flynn, Huo, \& Zhao, 2010, s. 60).

Literatürde tedarik zinciri entegrasyonunun çeşitli performans göstergeleri üzerindeki etkilerini inceleyen çalışmalara rastlanmaktadır. Örneğin; Shukor vd. (2020), tedarik zinciri entegrasyonunu müşteri, tedarikçi ve iç entegrasyon olmak üzere 3 boyutlu olarak ele almış ve bu boyutlar ile tedarik zinciri çevikliği ve operasyonel esneklik arasındaki ilişkileri imalat firmaları üzerinde araştırmışlardır. Benzer şekilde Jajja vd. (2018), tedarikçi, müşteri ve içsel entegrasyonun çeviklik performansı üzerindeki etkilerini test etmişlerdir. Bir başka çalışmada ise Sayan (2018), lojistik, pazarlama ve üretim arasındaki içsel entegrasyonun tedarik zincirinin süre odaklı performansına etkisini araştırmıştır. Devaraj vd. (2007), tedarikçi ve müşteri entegrasyonunun operasyonel performans üzerindeki etkisini; maliyet, kalite, esneklik ve dağıtım açısından incelemişlerdir. Ayrıca Ramirez vd. (2021), TZE'nin operasyonel performans üzerindeki etkisini, Latin Amerika tarım-gıda endüstrisinde ampirik olarak değerlendirmişlerdir. Germain ve Iyer (2006), entegrasyonu içsel entegrasyon ve aşağı yönde entegrasyon olarak iki boyutta çalışış ve bu boyutların lojistik performans üzerindeki etkisini irdelemişlerdir. Yıldız ve Çetindaş (2020) ise tedarik zinciri entegrasyonu ile tedarik zinciri esnekliği arasındaki ilişkiyi incelemişlerdir. Benzer bir başka çalışmada esneklik, entegrasyon ve tedarik zinciri 
risk yönetimi, arasındaki ilişkiler ele alınmışır (Chaudhuri, Boer, \& Taran, 2018, s. 691). Son olarak Wang ve Zhang (2020), müşteri, tedarikçi ve içsel entegrasyonun esneklik üzerindeki etkilerini araştırmışlardır. Literatürde TZE ile çeşitli performans göstergeleri arasındaki ilişkiye odaklanan çok sayıda çalışma bulunmasına rağmen bu konuda henüz fikir birliği oluşturulmuş değildir. Bu durum, TZE ile performans arasında her zaman net bir ilişkinin bulunamamış olmasından kaynaklanmaktadır (Alfalla-Luque, MedinaLopez, \& Dey, 2013, s. 812). Flynn vd. (2010), TZE’nin performans ile ilişkisini tamamen anlayabilmek için TZE'nin farklı boyutlarının farklı performans göstergeleri ile nasıl ilişkili olduğuna dair araştırmalar yapılması gerektiğini vurgulamaktadırlar. Dolayısıyla farklı performans göstergelerini ve TZE'yi farklı boyutlarla ele alan daha fazla araştırmanın yapılmasına ihtiyaç vardır. Literatürdeki bu bulgulara dayalı olarak aşağıdaki hipotezler geliştirilmiştir.

H1: Müşteri entegrasyonu operasyonel çevikliği pozitif yönde etkilemektedir.

H2: Tedarikçi entegrasyonu operasyonel çevikliği pozitif yönde etkilemektedir.

H3: İç entegrasyon operasyonel çevikliği pozitif yönde etkilemektedir.

\subsubsection{Tedarik Zinciri Entegrasyonunun Kitlesel Kişiselleştitme Yeteneği Üzerindeki Etkisi}

Müşteri ve tedarikçi entegrasyonu, işletmenin stratejik öneme sahip bilgiler edinmesini mümkün kılmaktadır. Örneğin, müşteri entegrasyonu, bir işletmenin müşterilerinin özel ihtiyaçlarını doğru bir şekilde belirlemesine yardımc1 olacak bilgiler sağlarken tedarikçi entegrasyonu bir işletmenin çeşitlenmiş müşteri talebini karşılamak için gerekli malzeme ve parça tedarikini daha etkili ve verimli bir şekilde elde etmesine katk1 sunacak bilgiler sağlayacaktır (Liu, Zhang, \& Guo, 2018, s. 611). Elde edilen bu bilgiler sayesinde ürün teslim süreleri kısalacak, stok kontrolünün verimliliği artacak ve belirsizlik azalacaktır (Munir, Jajja, Chatha, \& Farooq, 2020, s. 3) ki bu sayede kitlesel kişiselleştirme yapabilmek kolaylaşacaktır. Fakat kitlesel kişiselleştirme yeteneği elde etmek sadece dişsal faktörlere değil aynı zamanda içsel faktörlere de bağlıdır. Liu vd. (2006), kitlesel kişiselleştirme yeteneğini arttıran temel faktörlerden birinin işletme içinde işin organize edilme şekli olduğunu vurgulamaktadır. Dolayısıyla işletmenin örgüt içerisindeki faaliyetlere odaklanmasını niteleyen iç entegrasyonun kitlesel kişiselleştirme yeteneğini arttırması beklenmektedir. Sonuç olarak, tedarik zinciri genelinde bir entegrasyon sağlandığında bu entegrasyon işletmenin müşteri talebini tam olarak değerlendirmesine, gerekli kaynakları başarıyla elde etmesine ve üretim sürecindeki tüm kaynakları etkin bir şekilde düzenlemesine olanak tanımaktadır. Bunun sonucu olarak işletme, müşterilerine yüksek kaliteli özelleștirilmiş ürünleri, hızlı ve uygun maliyetli bir şekilde sunabilecektir ki bu durum kitlesel kişiselleştirmenin özünü oluşturmaktadır (Liu, Zhang, \& Guo, 2018, s. 611).

Literatürde, kitlesel kişiselleştirme yeteneği elde edebilmek için farklı değişkenlerin bu yetenek üzerindeki etkileri incelenmiştir. Örneğin; Liu ve Deitz (2011), yürüttükleri araştırmada işletmenin müşteri odaklı ürün tasarımı yapmasının kitlesel kişiselleştirme yeteneğini olumlu yönde geliştirdiğini tespit etmişlerdir. Zhang vd. (2014)'nin ampirik olarak test ettiği araştırmanın bulguları, fonksiyonlar arası koordinasyonun ve tedarik zinciri koordinasyonunun kitlesel kişiselleştirme yeteneğini geliştirmeye önemli ölçüde katkı sağladığını göstermiştir. Liao vd. (2011) ise üretici ve tedarikçi arasındaki bilgi paylaşımının kitlesel kişiselleştirmeyi artırdığını belirlemişlerdir. Son olarak Lai vd. (2012), talebin belirsiz ve rekabetin yoğun olduğu koşullarda, müşteri ve içsel entegrasyonun doğrudan kitlesel kişiselleştirme yeteneğini geliştirdiği sonucuna varmışlardır. Literatürdeki bu bulgulara paralel olarak $\mathrm{H} 4, \mathrm{H} 5$ ve $\mathrm{H} 6$ hipotezleri geliştirilmiştir.

H4: Müşteri entegrasyonu kitlesel kişiselleştirme yeteneğini pozitif yönde etkilemektedir.

H5: Tedarikçi entegrasyonu kitlesel kişiselleştirme yeteneğini pozitif yönde etkilemektedir.

H6: İç entegrasyon kitlesel kişiselleştirme yeteneğini pozitif yönde etkilemektedir.

\subsubsection{Operasyonel Çevikliğin Kitlesel Kişiselleştirme Yeteneği Üzerindeki Etkisi}

Son y1llarda kitlesel kişiselleştirme çabaları çoğunlukla çeviklik üzerine yoğunlaşmaktadır (Wang W. P., 2009, s. 3439-3440). Çünkü çeviklik; fiyat, kalite, kişiselleștirme ve teslim tarihleri de dahil olmak üzere müşteri gereksinimlerindeki değişikliklerle başa çıkmayı kolaylaştırmaktadır (Wang W. P., 2009, s. 3440). Bu konuda çalışma yapan yazarlar da çevikliğin kitlesel kişiselleştirme için önemli olduğunu ifade etmektedirler. Örneğin; Da Silveira vd. (2001), yaptıkları literatür araştırmasında kitlesel kişiselleştirme ile ilgili dört iş uygulamasının varllğına dikkat çekmişlerdir. Bu uygulamalar; çevik üretim, tedarik zinciri yönetimi, müşteri odaklı tasarım 
ve yalın üretimdir (Da Silveira, Borenstein, \& Fogliatto, 2001, s. 5). Barutcu (2007) ise kişiselleştirilmiş ürünlerin üretilebilmesi için pazarlamaya, üretime, tedarike ve lojistiğe farklı stratejiler entegre edilmesi gerektiğini belirtmiştir. Bu stratejiler; ilişkisel pazarlama, tedarik zinciri yönetimi, çevik üretim ve kitlesel kişiselleştirmedir. Yazar, bu stratejilerin kişiselleştirilmiş ürünler için bir altyapı çerçevesi görevi gördüğünü vurgulamıştır (Barutcu, 2007, s. 575). Wang (2009), kitlesel kişiselleştirme stratejilerini uygulamak için en uygun çevik üretim sistemini belirlemek adına TOPSís yöntemini kullanarak bir yaklaşım geliştirmeye çalışmıştır. Benzer şekilde Mishra vd. (2013) de kitlesel kişiselleştirme stratejilerini uygulamak için en uygun çevik sistemi belirlemek adına bulanık TOPSİS yönteminden yararlanmışlardır. Yazarlar, kitlesel kişiselleştirmeyi geliştirmek için beş çeviklik kriterini dikkate almışlardır. Bunlar; yönetim çevikliği, ürün tasarımı çevikliği, üretim çevikliği, ortaklık oluşturma çevikliği ve bilgi sistemi entegrasyonu çevikliğidir (Mishra, Datta, \& Mahapatra, 2013, s. 450). Yukarıdaki çalışmalar, çevikliğin kitlesel kişiselleştirme için önemli olduğunu öne sürmektedirler. Ancak bu iki kavram arasındaki ilişkiyi ampirik olarak inceleyen çalışmalara da ihtiyaç olduğu görülmektedir.

H7: Operasyonel çeviklik kitlesel kişiselleştirme yeteneğini pozitif yönde etkilemektedir.

\section{ARAŞTIRMA METODOLOJİSİ}

\subsection{Veri Toplama Yöntemi ve Örneklem Yapısı}

Araştırmada herhangi bir sınırlamaya (sektör, büyüklük, bölge gibi) gidilmediği için örneklem çerçevesini belirlemek zorlaşmaktadır. Bu yüzden kolayda örnekleme yöntemi tercih edilmiştir. Bu yöntem kullanılarak 83 işletme üzerinde anket uygulaması gerçekleştirilmiştir. Veriler 2020 yılı öncesinde toplanmıştır.

\subsection{Anket Ölçeklerinin Oluşturulması}

$\mathrm{Bu}$ araştırmada, tedarik zinciri entegrasyonu, operasyonel çeviklik ve kitlesel kişiselleştirme yeteneği olmak üzere üç değişken yer almaktadır. Her üç değişken için de literatürde geçerliliği ve güvenilirliği test edilmiş ölçekler bulunması nedeniyle bu ölçeklerden faydalanılmıştır. TZE ile ilgili literatür incelendiğinde, bu kavramın ölçülmesiyle ilgili olarak birçok farklı ölçeğin kullanıldığı görülmektedir. Örneğin Xu vd. (2014), TZE'yi müşteri entegrasyonu ve tedarikçi entegrasyonu olarak iki boyutta çalşsmışlar ve toplam 24 maddeden oluşan bir ölçek kullanmışlardır. Prajogo ve Olhager (2012) ise TZE'yi bilgi entegrasyonu ve lojistik entegrasyonu olarak ölçümlemişlerdir. Rai vd. (2006), süreç entegrasyonu şeklinde ele aldıkları TZE'yi, bilgi akışı entegrasyonu, fiziksel akış entegrasyonu ve finansal akış entegrasyonu olarak üç boyutta incelemişlerdir. Bazı yazarlar ise TZE'yi tek boyutlu olarak ölçmüsslerdir (Alfalla-Luque, Medina-Lopez, \& Dey, 2013, s. 801). Alfalla-Luque vd. (2013) tarafindan yapılan literatür araştırmasına göre TZE, genel olarak müşteri, tedarikçi ve iç entegrasyon olarak üç ana boyut altında değerlendirilmektedir. Buradan yola çıkarak bu çalışmada TZE için hem iç hem de diş entegrasyonu (müşteri-tedarikçi) kapsayacak şekilde bir ölçüm aracı kullanılmıştır. Bu üç boyut için Lai vd. (2012)'nin kullandığ 12 maddeden oluşan ölçekten yararlanılmıştır. Müşteri entegrasyonu; işletme ve müşterisi arasındaki stratejik ortaklık, yakın temas ve bütünleştirici uygulamalarla ilgili dört madde kullanılarak ölçülmüştür. Tedarikçi entegrasyonu için işletme ve tedarikçisi arasındaki uzun vadeli iş birliği ilişkileri, işletmeler arası iletişim ve birlikte geliştirme uygulamaları ile ilgili dört madde kullanılmıştır. Müşteri ve tedarikçi entegrasyonuyla ilgili maddeler, bir işletmenin tedarik zinciri ortaklarıyla birlikte çalışarak örgütler arası ilişkileri ve süreçleri yönetme becerisini değerlendirmektedir. Yöneticilerin bu maddelere verdikleri yanttlar, müşteri ve tedarikçi entegrasyonunu hem operasyonel düzeyde hem de stratejik düzeyde ölçmemizi sağlamaktadır. İç entegrasyon; iş birliğine dayalı karar verme, fonksiyonlar arası iyi ilişkiler kurma ve iş birliğiyle ilgili dört maddeyle ölçülmüştür. Bu maddeler, bir işletmenin yatay bağlantılar yakalayarak örgüt içi ilişkileri ve süreçleri yönetme becerisini ve departmanlar arasındaki iş birliğini değerlendirmektedir (Lai, Zhang, Lee, \& Zhao, 2012, s. 448).

Operasyonel çevikliğin ölçülmesi için ise Akhtar vd. (2018)'nin çalışması referans alınmıştır. Yazarlar, diğer çalışmalardan farklı olarak geleneksel operasyonel çeviklik kavramını makro ve mikro çevre temeline dayanarak geliştirmişler ve bu kavramı iç ve dış operasyonel çeviklik şeklinde incelemişlerdir. Fakat bu çalışmada operasyonel çeviklik, literatürdeki diğer çalışmalarda olduğu gibi tek boyutlu bir şekilde ele alınmıştır (Akhtar, Khan, Tarba, \& Jayawickrama, 2018, s. 312-313). Bu ölçek, çevikliğin dört bileşeni olan yetkinlik, esneklik, cevap verebilirlik ve hız maddelerinden oluşmaktadır. 
Son olarak, çalışmanın bağımlı değişkeni olan kitlesel kişiselleştirme yeteneği için Zhang vd. (2015)'nin ölçeği tercih edilmiştir. Bu ölçekte kitlesel kişiselleştirme yeteneğinin dört bileşenini ölçmek için altı madde kullanılmıştır. $\mathrm{Bu}$ dört bileşen, yüksek hacimli kişiselleştirme, kişiselleştirmede maliyet verimliliği, kişiselleştirmede yanıt süresi ve kişiselleştirmede kalitedir. Bu ölçekteki ilk dört madde yüksek hacim, maliyet verimliliği ve kaliteye vurgu yapmaktadır. Ürün ve süreç tasarımlarının müşteri taleplerine göre ayarlanmasıyla ilgili olan son iki madde ise süreç esnekliğini ve kişiselleştirmeye yanıt verebilirliği ölçmek için kullanılmıştır. Böylelikle bu maddeler ile üretim süreçlerinin hızlı bir şekilde yeniden düzenleme yeteneği üzerinde durulmaktadır (Zhang, Zhao, Lyles, \& Guo, 2015, s. 1281). Bazı işletmeler tam anlamıyla kitlesel kişiselleştirme yapmayabilir ancak yine de kitlesel kişiselleştirmeyle ilgili stratejik değişimlerle karşı karşıyadırlar. Yöneticilerin bu maddelere verdikleri yanıtlar, işletmelerin kitlesel kişiselleştirme derecesini ölçmemize olanak tanımaktadır. Yukarıda bahsedilen kaynaklardan orijinal maddeler derlendikten sonra, tespit edilen ölçüm maddeleri Türkçeye çevrilmiştir. Sonuç olarak, toplamda 22 ölçüm maddesinden oluşan ankette, cevaplar için 5'li Likert ölçeği kullanılmıştır (Ek 1) (1= kesinlikle katılmıyorum, $5=$ kesinlikle katiliyorum).

\section{3. Örneklemin Özellikleri}

Anketi cevaplayan işletmelere ilişkin tanımlayıcı istatistiki bilgiler Tablo 1'de yer almaktadır. Tablo 1'de görüldügüü üzere, ankete cevap veren işletmelerden $\% 19$ 'u tekstil, \%13'ü otomotiv yan sanayi, \%6'sı mobilya, $\% 17$ 'si elektrik-elektronik, \%18'i gıda, \%10'u makine, \%8'i plastik-kauçuk, \%5'i kimya sektöründe faaliyet göstermektedir. Ankete cevap veren işletmeler çalışan sayısı açısından değerlendirildiğinde ise $\% 25 \%$ i 50 'den daha az, \%38'i 50-249 aras1, \%20'si 250-499 arası, \%13'ü 500-1000 arası ve \%2'si ise 1000 kişiden daha fazla çalışana sahiptir.

Ankete cevap verenlerin eğitim durumlarına bakıldı̆̆ında \%22'si lise, \%60’’ üniversite, $\% 11$ ’i yüksek lisans ve \%7'si doktora mezunudur. Bu kişilerin \%13'ü 2 yildan az, \%29'u 2-5 y1l arası, \%33'ü 6-10 yıl arası ve $\% 25$ ’ ise 10 ylldan daha fazla deneyime sahiptir. Tablo 1'de ankete cevap verenlerin yönetici konumunda olduğu görülmektedir. Bu nedenle, anketin uzman kişiler tarafindan cevaplandığı söylenebilir. Genel müdür $\% 17^{\prime} l i k$, işletme sahibi $\% 30$ 'luk, üretim müdürü \%19'luk, lojistik yöneticisi $\% 18^{\prime}$ lik, tedarik zinciri yöneticisi $\% 11^{\prime}$ lik ve satın alma yöneticisi $\% 5$ 'lik orana sahiptir. 
Tablo 1. Katılımcıların Özellikleri

\begin{tabular}{|c|c|c|}
\hline Sektörler & Frekans & Yüzde (\%) \\
\hline Tekstil & 16 & 19.27 \\
\hline Otomotiv yan sanayi & 11 & 13.25 \\
\hline Mobilya & 5 & 6.02 \\
\hline Elektrik-Elektronik & 14 & 16.86 \\
\hline Gida & 15 & 18.07 \\
\hline Makine & 8 & 9.63 \\
\hline Plastik-Kauçuk & 7 & 8.43 \\
\hline Kimya & 4 & 4.81 \\
\hline Diğer & 3 & 3.61 \\
\hline Toplam & 83 & 100 \\
\hline \multicolumn{3}{|l|}{ Çalışan Sayısı } \\
\hline $50^{\prime}$ den az & 21 & 25.30 \\
\hline $50-249$ & 32 & 38.55 \\
\hline $250-499$ & 17 & 20.48 \\
\hline $500-1000$ & 11 & 13.25 \\
\hline 1,000 'den fazla & 2 & 2.40 \\
\hline Toplam & 83 & 100 \\
\hline \multicolumn{3}{|l|}{ İş Unvanı } \\
\hline Genel Müdür & 14 & 16.87 \\
\hline İşletme Sahibi & 25 & 30.12 \\
\hline Üretim Müdürü & 16 & 19.27 \\
\hline Lojistik Yöneticisi & 15 & 18.07 \\
\hline Tedarik Zinciri Yöneticisi & 9 & 10.84 \\
\hline Satın Alma Yöneticisi & 4 & 4.82 \\
\hline Toplam & 83 & 100 \\
\hline \multicolumn{3}{|l|}{ Eğitim Durumu } \\
\hline Lise & 18 & 21.68 \\
\hline Üniversite & 50 & 60.24 \\
\hline Yüksek Lisans & 9 & 10.84 \\
\hline Doktora & 6 & 7.22 \\
\hline Toplam & 83 & 100 \\
\hline \multicolumn{3}{|l|}{ Deneyim } \\
\hline 2 yildan az & 11 & 13.25 \\
\hline $2-5$ y1l & 24 & 28.91 \\
\hline 6-10 yil & 27 & 32.53 \\
\hline 10 yıldan fazla & 21 & 25.30 \\
\hline Toplam & 83 & 100 \\
\hline
\end{tabular}

\subsection{Ortak Yöntem Varyansı (Common Method Variance-CMV) Analizi}

Anket çalışmalarında kendi kendini değerlendirme yönteminin kullanılması ve farklı değişkenlerin aynı katılımcılar tarafindan aynı zaman diliminde cevaplanması durumunda ortak yöntem varyansı ortaya çıkabilir (Malhotra, Kim, \& Patil, 2006, s. 1865). Bu çalışmada CMV'nin olup olmadı̆̆ını tespit etmek için ilk olarak Harman'ın tek faktör testi yapılmıştır. Bu doğrultuda döngüsüz faktör analizine sokulan ölçüm maddeleri tek bir faktör altında toplanmamış ve açıklanan varyansın büyük bir oranı tek bir faktör tarafindan temsil edilmemiştir (Podsakoff, Mackenzie, Podsakoff, \& Lee, 2003, s. 889). Aşır1 yüksek korelasyon değeri CMV 
sorununa işaret edeceğinden (Lai, Zhang, Lee, \& Zhao, 2012, s. 450) bunu test etmek için ikinci olarak korelasyon katsayıları incelenmiştir. Sonuç olarak gerek korelasyon katsayıları gerekse Harman'in tek faktör testi bu çalışma için ortak yöntem varyansının bir sorun olmadığını ortaya koymaktadır.

\subsection{Analiz Tekniği}

Bu çalışmada veri analizi için kısmi en küçük kareler yapısal eşitlik analizi (PLS-YEM) tercih edilmiştir. PLS, ölçüm modelini ve yapılar arasındaki ilişkileri aynı anda değerlendiren ikinci nesil bir modelleme tekniğidir (Lai, Zhang, Lee, \& Zhao, 2012, s. 449). PLS-YEM, gizil değişkenler ve açıklayıcı değişkenler arasındaki ilişskileri ve modeldeki gizli değişkenleri, basit ve çoklu regresyon yöntemiyle tahmin etmektedir. AMOS ve LISREL gibi kovaryans temelli YEM ile karşılaştırıldığında PLS-YEM'in avantajları hatırı sayılır derecede fazladır. Örneğin; kovaryans temelli YEM’i uygulayabilmek için verinin normal dağılıma uygun olması ve yeterli veri büyüklüğüne sahip olunması gerekmektedir. PLS-YEM'in ise diğer çok değişkenli analiz tekniklerinde olduğu gibi çok sayıda varsayımı bulunmamaktadır. Örneğin; PLS-YEM normal dağılım varsayımı gerektirmemekte ve küçük örneklemde de etkin bir şekilde çalışabilmektedir. PLS-YEM ve kovaryans temelli YEM'i karşılaştıran çalışmalarda, örnek boyutu küçük olduğunda PLS'nin diğer yöntemlerden daha iyi performans gösterdiği belirtilmiştir (Çakar, 2020, s. 39-40). Bu çalsşmada örneklem büyüklügünün küçük olması nedeniyle PLS-YEM kullanılmıştır.

Söz konusu tekniğin son zamanlarda tedarik zinciri yönetimi ve üretim alanlarında yaygın olarak kullanıldığı görülmektedir. Örneğin; Xu vd. (2014), Çin'de yaptıkları araştırmada üst yönetim desteği ve bilgi teknolojilerinin tedarikçi ve müşteri entegrasyonu üzerindeki etkisini PLS-YEM yöntemiyle test etmişlerdir. Rai vd. (2006) de bilişim teknolojileri entegrasyonu yeteneği, tedarik zinciri süreç entegrasyonu ve firma performansı arasındaki ilişkilerin araştırılmasında PLS-YEM yöntemini kullanmışlardır. Shukor vd. (2020), belirsizlik, tedarik zinciri entegrasyonu (müşteri, tedarikçi ve iç), tedarik zinciri çevikliği ve örgütsel esneklik arasındaki ilişkileri PLS-YEM ile ölçmüşlerdir. Bir başka çalışmada ise kitlesel kişiselleştirme yeteneği, müşteri ve tedarikçiden bilgi edinme, bilgi asimilasyonu ve bilgi uygulaması değişkenleri arasındaki ilişkilerin test edilmesinde PLS-YEM yönteminin tercih edildiği görülmektedir (Zhang, Zhao, Lyles, \& Guo, 2015, s. 1284). Son olarak S. Liu vd. (2018), bulut altyapı yeteneğinin örgütsel çeviklik üzerindeki etkisini test ederken PLS-YEM yönteminden yararlanmışlardır.

\subsection{Geçerlilik ve Güvenilirlik Analizleri}

$\mathrm{Bu}$ araştırmada SMARTPLS ve SPSS programları kullanılarak geçerlilik ve güvenilirlik analizleri gerçekleştirilmiştir. İlk olarak SPSS programı ile keşifsel faktör analizi yapılmış ve analiz sonucunda değişkenlerin beklendiği gibi beş faktöre yüklendikleri görülmüştür. Bu aşamada faktör yükü düşük çkan "ME 4" ve "Çeviklik 3" maddeleri ölçekten çıkartılmıştır. Diğer değişkenlerin faktör yükünün 0.564-0.898 arasında olduğu tespit edilmiştir. Ölçeğin KMO (Örneklem yeterliliği ölçütü testi- Kaiser Meyer Olkin) değeri 0.780 , açılanan varyans ise 70.971 olarak bulunmuştur. Barlett küresellik testinin de anlamlı olduğu tespit edilmiştir. KMO değerinin 0.60 'tan yüksek olması ve Barlett testinin anlamlı olması bulgularına bakılarak veri setinin faktör analizi için uygun olduğu söylenebilir (Kalayc1, 2008, s. 322). Daha sonra SMARTPLS kullanılarak doğrulayıcı faktör analizi ortaya konmuştur.

Doğrulayıcı faktör analizine göre faktör yükü düşük çıkan "İE 4" maddesi ölçekten çıartılmıştır. Doğrulayıc1 faktör analizi sonuçları, yakınsak ve ayrışma geçerliliğini analiz etmek için kullanılmıştır. Yakınsak geçerliliği, söz konusu ölçeğin aynı yapıyı ölçen diğer ölçütlerle ne derece örtüştügünün göstergesidir. Yakınsak geçerliliği analiz etmek için Cronbach alfa, Bileşik Güvenilirlik (Composite Reliability-CR), Çıkarılan Ortalama Varyans (Average Variance Extracted-AVE) değerleri ve faktör yükleri incelenmiştir (Merschmann \& Thonemann, 2011, s. 48). Tablo 2'de görüldüğü üzere alfa değeri ve CR değeri kritik değer olan 0.70 'in üzerindedir. AVE değerinin ise 0.50 'den yüksek olması gerekmektedir (Merschmann \& Thonemann, 2011, s. 48). Araştırmada elde edilen AVE değerlerinin 0.597-0.810 arasında olduğu görülmektedir. Yakınsak geçerliliğin değerlendirilmesi için son olarak faktör yüklerinin anlamlılı̆ına bakılmıştır. Yüklerin anlamlllŏı̆n değerlendirmek için bootstrapping yaklaşımı kullanılmış ve faktör yüklerinin $\mathrm{t}$ değerlerinin $\mathrm{p}<0.01$ düzeyinde anlamlı olduğu ortaya çıkmıştır. Bu sonuçlardan hareketle yakınsak geçerliliğinin sağlandığı düşünülmektedir. 
Tablo 2. Doğrulayıcı Faktör Analizi Sonuçları

\begin{tabular}{|c|c|c|c|c|c|c|c|c|c|}
\hline & Müşteri E. & İç Ent & Tedarikçi E. & Çeviklik & Kitlesel K. & t değerleric & AVE & CR & Alfa \\
\hline ME 1 & 0.765 & & & & & 10.023 & 0.716 & 0.883 & 0.800 \\
\hline ME 2 & 0.896 & & & & & 22.416 & & & \\
\hline ME 3 & 0.871 & & & & & 19.374 & & & \\
\hline ME 4a & - & & & & & & & & \\
\hline$\dot{\text { İE } 1}$ & & 0.909 & & & & 37.875 & 0.810 & 0.927 & 0.882 \\
\hline İE 2 & & 0.928 & & & & 46.766 & & & \\
\hline İE 3 & & 0.861 & & & & 20.675 & & & \\
\hline İE 4b & & - & & & & - & & & \\
\hline TE1 & & & 0.633 & & & 4,809 & 0.630 & 0.871 & 0.809 \\
\hline TE2 & & & 0.854 & & & 16.444 & & & \\
\hline TE3 & & & 0.876 & & & 22.245 & & & \\
\hline TE4 & & & 0.790 & & & 10.703 & & & \\
\hline Çeviklik1 & & & & 0.872 & & 16.690 & 0.740 & 0.895 & 0.825 \\
\hline Çeviklik2 & & & & 0.882 & & 28.711 & & & \\
\hline Çeviklik3a & & & & - & & - & & & \\
\hline Çeviklik4 & & & & 0.825 & & 19.064 & & & \\
\hline KK1 & & & & & 0.727 & 11.099 & 0.597 & 0.898 & 0.866 \\
\hline KK2 & & & & & 0.868 & 26.954 & & & \\
\hline KK3 & & & & & 0.684 & 5.854 & & & \\
\hline KK4 & & & & & 0.721 & 7.907 & & & \\
\hline KK5 & & & & & 0.782 & 15.544 & & & \\
\hline KK6 & & & & & 0.836 & 20.347 & & & \\
\hline $\begin{array}{l}\text { aKeşifsel fa } \\
\text { bİE } 4 \text { madd } \\
\text { c Tüm fakt } \\
\text { ME=Müşte }\end{array}$ & $\begin{array}{l}\text { analizi son } \\
\text { doğrulayıc1 } \\
\text { ikleri } 0.01 \mathrm{~d} \\
\text { ntegrasyon }\end{array}$ & $\begin{array}{l}\text { nda MF } \\
\text { ör anali } \\
\text { eyinde a } \\
\mathrm{E}=\dot{\mathrm{I}} \mathrm{c} \text { E }\end{array}$ & $\begin{array}{l}\text { ve Çeviklik } 3 \\
\text { sonucunda f } \\
\text { amlıdır. } \\
\text { egrasyon, TE }\end{array}$ & $\begin{array}{l}\text { ddeleri fa } \\
\text { yükü dü } \\
\text { darikçi E }\end{array}$ & $\begin{array}{l}\text { yükü düşü } \\
\text { :ktı̆g } 1 \text { için } \\
\text { rasyonu, K }\end{array}$ & $\begin{array}{l}\text { tı̆̆ için ç1 } \\
\text { zten çıart } \\
\text { Kitlesel Ki }\end{array}$ & $\begin{array}{l}\text { almıştır. } \\
\text { ştır } \\
\text { lleştirme }\end{array}$ & & \\
\hline
\end{tabular}

Ayrışma geçerliliği ise bir yapıya ilişkin ölçek ile farklı yapıları ölçen ölçekler arasında zayıf bir ilişkinin, yani düşük korelasyonun olması anlamına gelmektedir. Bu çalışmada ayrışma geçerliliğinin değerlendirilmesinde iki prosedür kullanılmıştır. İlk olarak Fornell-Larcker kriteri dikkate alınmıştır. Bu kritere göre ayrışma geçerliliğinin sağlanabilmesi amacıyla her bir yapı için hesaplanan AVE'nin karakökü, yapılar arasındaki korelasyondan daha büyük olmalıdır (Çakar, 2020, s. 70). Tablo 3'te her bir yapının AVE değerinin karakökünün (köşegen elemanları) yapılar arasındaki korelasyon katsayılarından daha büyük olduğu görülmektedir. Ayrışma geçerliliğinin test edilmesi için kullanılan diğer bir yöntem ise Heterotrait Monotrait oranıdır (HTM). İki faktör arasında açıkça ayrım yapabilmek için bu oranın 1'den önemli ölçüde küçük olması gerekmektedir (Henseler, Hubona, \& Ray, 2016, s. 11). Bu oranın 0.85 ya da 0.90 'dan büyük olması, ayrışma geçerliliğinin sağlanamadı̆̆ını göstermektedir (Çakar, 2020, s. 72). Tablo 4'teki HTM oranlarına baktığımızda tüm değerlerin 0.85 'den küçük olduğu anlaşılmaktadır. Bu sonuçlar doğrultusunda ayrışma geçerliliğinin sağlandığı düşünülmektedir.

Tablo 3. Ayrışma Geçerliliği (Fornell-Lacker Ölçütü) ve Değişkenler Arasındaki Korelasyon Katsayıları

\begin{tabular}{|c|c|c|c|c|c|}
\hline & Müşteri E. & İç Ent & Tedarikçi E. & $\begin{array}{c}\text { Operasyonel } \\
\text { Çeviklik }\end{array}$ & Kitlesel K. \\
\hline Müşteri Entegrasyonu & 0.846 & & & & \\
\hline İç Entegrasyon & 0.316 & 0.900 & & & \\
\hline Tedarikçi Entegrasyonu & 0.275 & 0.196 & 0.794 & & \\
\hline Operasyonel Çeviklik & 0.272 & 0.521 & 0.212 & 0.860 & \\
\hline Kitlesel Kişiselleştirme & 0.361 & 0.293 & 0.404 & 0.208 & 0.773 \\
\hline
\end{tabular}


Tablo 4. Ayrışma Geçerliliği (Heterotrait-Monotrait Ratio (HTM))

\begin{tabular}{lcccc}
\hline & Müşteri E. & İç Ent & Tedarikçi E. & $\begin{array}{c}\text { Operasyonel } \\
\text { Çeviklik }\end{array}$ \\
\hline Müşteri Entegrasyonu & - & & & \\
\hline İç Entegrasyon & 0.379 & & & \\
\hline Tedarikçi Entegrasyonu & 0.307 & 0.225 & 0.241 & 0.223 \\
\hline Operasyonel Çeviklik & 0.331 & 0.598 & 0.445 & 0.312 \\
\hline Kitlesel Kişiselleştirme & 0.399 & & & \\
\hline
\end{tabular}

\subsection{Araştırma Bulguları}

Yapısal modeli test etmek için SmartPLS programı kullanılmıştır. Tablo 5'te ilişkilerin standardize edilmiş katsayıları ( $\beta$ değerleri) ve bootstrapping yaklaşımıla hesaplanan t değerleri görülmektedir. Bu model, kitlesel kişiselleştirmedeki varyansın $\left(\mathrm{R}^{2}\right.$ Kitlesel) $\% 25.1$ 'ini ve operasyonel çeviklikteki varyansın $\left(\mathrm{R}^{2}\right.$ çevillik $)$ ise \%29.2'sini açıllamaktadır. Cohen, R²’nin etki boyutunu şu şekilde sınıflandırmaktadır: Küçük 0.02, orta 0.13 ve büyük 0.26 (Xu, Huo, \& Sun, 2014, s. 1198). Bu sinıflandırma temel alındığında, operasyonel çevikliğin büyük etki boyutlarına sahip olduğu, kitlesel kişiselleştirme yeteneğinin etki boyutunun ise orta düzeyde olduğu anlaşılmaktadır.

Tablo 5'teki analiz sonuçlarına bakıldığında, tedarik zinciri entegrasyonunun üç boyutundan sadece iç entegrasyonun çeviklik üzerinde pozitif ve anlamlı bir etkisi olduğu belli olmaktadır $(\beta=0.472 ; \mathrm{t}=4.945$; $\mathrm{p}<0,01$ ). İç entegrasyonun çeviklik üzerindeki etki büyüklüğü (effect size- $\mathrm{f}^{2}$ ) ise 0.279 'dur. Bu değere bakarak iç entegrasyonun çeviklik üzerinde orta düzeyde bir etkisinin olduğundan söz edilebilir (Henseler, Hubona, \& Ray, 2016, s. 12). Bir diğer değişken olan operasyonel çevikliğin ise kitlesel kişiselleştirme üzerinde anlamlı bir etkisi tespit edilememiştir $(\mathrm{H} 7) \quad(\beta=-0.005 ; \mathrm{t}=0.043 ; \mathrm{p}>0.05)$. Ayrıca müşteri entegrasyonunun ve tedarikçi entegrasyonunun kitlesel kişiselleştirme üzerinde anlamlı bir etkisi belirlenirken, iç entegrasyonun anlamlı bir etkisi bulunamamıştır.

Sonuç olarak H3, H4 ve H5 hipotezleri kabul edilirken, H1, H2, H6 ve H7 hipotezleri reddedilmiştir.

Tablo 5. Yapısal Model Sonuçları

\begin{tabular}{lcccccccccc}
\hline & \multicolumn{4}{c}{ Operasyonel Çeviklik } & \multicolumn{5}{c}{ Kitlesel Kişiselleştirme } \\
\hline & $\beta$ & $\mathbf{t}$ değeri & $\mathbf{s i g}$ & $\mathbf{f}^{2}$ & $\mathbf{V I F}^{*}$ & $\beta$ & $\mathbf{t}$ değeri & sig & $\mathbf{f}^{2}$ & VIF* $^{*}$ \\
\hline Müşteri & 0.096 & 0.943 & 0.346 & 0.011 & 1.172 & $\underline{\mathbf{0 . 2 2 0}}$ & $\underline{\mathbf{1 . 8 9 8}}$ & $\underline{\mathbf{0 . 0 5 8}}$ & $\underline{\mathbf{0 . 0 5 5}}$ & $\underline{\mathbf{1 . 1 8 6}}$ \\
\hline İç Ent & $\underline{\mathbf{0 . 4 7 2}}$ & $\underline{\mathbf{4 . 9 4 5}}$ & $\underline{\mathbf{0 . 0 0 0}}$ & $\underline{\mathbf{0 . 2 7 9}}$ & $\underline{\mathbf{1 . 1 2 7}}$ & 0.157 & 1.301 & 0.194 & 0.023 & 1.442 \\
\hline Tedarikçi & 0.094 & 0.842 & 0.400 & 0.011 & 1.098 & $\underline{\mathbf{0 . 3 1 4}}$ & $\underline{\mathbf{3 . 0 3 5}}$ & $\underline{\mathbf{0 . 0 0 3}}$ & $\underline{\mathbf{0 . 1 1 9}}$ & $\underline{\mathbf{1 . 1 1 0}}$ \\
\hline Çeviklik & & & & & -0.005 & 0.043 & 0.965 & 0.000 & 1.412 \\
\hline & & & & & & & & $\mathrm{R}^{2}=0.251$ & &
\end{tabular}

Notlar: * Tüm VIF değerlerinin onun altında olması çoklu doğrusal bağlantı sorunu olmadığını göstermektedir (Kumar \& Banerjee, 2012, s. 907).

\section{SONUÇ}

Hızla değişen müşteri gereksinimleri ve yoğun rekabet ortamında işletmeler, rekabet avantajı kazanabilmek için hem seri üretimdeki gibi uygun fiyatlı hem de kişiselleştirilmiş ürün sunmak zorunda kalmaktadırlar. Bu nedenle kitlesel kişiselleştirme yeteneği, müşteri ihtiyaçlarını düşük maliyetli bir şekilde karşılamak için önemli bir rekabet faktörü haline gelmiştir. İşletmelere rekabet avantajı kazandırabilecek bir diğer konu ise çevikliktir. Günümüzde işletmelerin tehditleri ve firsatları kolayca algılama ve bunlara cevap verebilme yeteneğine, yani çevik olabilme yeteneğine de sahip olmaları gerekmektedir. Dolayısıyla kitlesel kişiselleştirme yeteneğini ve operasyonel çeviklik yeteneğini artırabilmenin bir yolunu bulmak hem araştırmacılar hem de uygulayıcılar için oldukça önemlidir. Bu çalışma, tedarik zinciri entegrasyonu, operasyonel çeviklik ve kitlesel kişiselleştirme kavramları arasındaki ilişkileri inceleyerek literatüre katkıda bulunmayı amaçlamaktadır. Bu amaç doğrultusunda yedi tane hipotez oluşturulmuş ve bu hipotezleri test etmek için PLS-YEM analizi kullanılmıştır. Tedarik zinciri entegrasyonunun operasyonel çeviklik üzerindeki etkisini incelemek için oluşturulan üç hipotezden (H1, H2 ve H3) sadece iç entegrasyonun çeviklik (H3) 
üzerinde pozitif ve anlamlı bir etkisi olduğu tespit edilmiştir. İç entegrasyon ile çeviklik arasında elde edilen bu pozitif ilişkinin literatür ile uyumlu olduğu anlaşılmaktadır. Örneğin, Sayan (2018)'nın yaptığı çalışmada iç entegrasyonun tedarik zincirinin süre odaklı performansını pozitif yönde etkilediği görülmüsstür. Benzer şekilde Jajja vd. (2018) de iç entegrasyonun çeviklik performansı üzerindeki pozitif yönde ilişkisini ortaya koymuşlardır. Yıldız ve Çetindaş (2020)'ın Türkiye'de yaptıkları çalışmada, tek boyutlu bir şekilde inceledikleri TZE'nin tedarik zinciri çevikliği üzerinde pozitif etkisi olduğu belirlenmiştir. Bir başka çalışmada ise Wang ve Zhang (2020), müşteri, tedarikçi ve iç entegrasyon olarak üç boyutlu bir şekilde ele aldıkları TZE’nin çeviklik bileşenlerinden biri olan esneklik ile ilişkisini araştırmışlardır. Yazarlar, iç entegrasyonun ve tedarikçi entegrasyonunun esnekliği pozitif yönde etkilediğini göstermişlerdir. Ayrıca esneklik üzerinde en yüksek etkiye sahip olan boyutun iç entegrasyon olduğunu da belirtmişlerdir (Wang \& Zhang, 2020, s. 1157). Son olarak Chaudhuri vd. (2018), iç ve dış entegrasyonun esneklik üzerindeki etkilerini incelemişler ve sadece iç entegrasyonun esnekliği pozitif bir şekilde etkilediğini bulmuşlardır.

İç entegrasyon, işletmedeki faaliyetlerin verimliliğini ve etkinliğini artırmak için örgütün işlevsel birimleri arasındaki iletişimi artırmaktadır. Artan bu iletişim ve entegre edilen eylemler, daha kısa sürede ürün geliştirmeye, daha fazla ürün çeşidi üretebilmeye ve daha esnek bir yapıya sahip olmaya imkân tanımaktadır. Çünkü departmanlar arası engeller ortadan kaldırıldığında ve iş birliği sağlandığında işletme içerisindeki iç çatışmalar hızla çözülecek ve siparişi karşılamak için gereken bilgi, işletme içerisinde hızlı bir şekilde ilerleyecek ve böylece müşteri ihtiyaçları minimum sürede karşılanacaktır. Ayrıca iç paydaşların üretim planlama ve uygulama aşamasına erken ve etkili bir şekilde dahil edilmesi, sağlam ve duyarlı stratejiler hazırlamaya yardımcı olabilecektir. Literatür bölümünde de belirtildiği gibi, çevik olabilmek için sadece hızlı olmak yeterli değildir. Çevikliğin diğer bileşenlerinin de sağlanması gerekmektedir. Yukarıdaki ifadelerden de anlaşılacağı üzere iç entegrasyon, işletmelere sadece hız konusunda yardımcı olmakla kalmamakta, aynı zamanda çevikliği ölçmek için kullandığımız esneklik ve cevap verebilirlik gibi diğer bileşenlerin etkili bir şekilde yerine getirilmesini de sağlamaktadır. Özetle; pazar ihtiyaçlarına etkin, güvenilir ve hızlı cevap verebilmek, departmanlar arasında iş birliğini zorunlu kilmaktadır.

Araştırmada operasyonel çevikliğin kitlesel kişiselleştirme üzerinde etkisi tespit edilememiştir. Bu bulgu oldukça şaşırtıcıdır. Çünkü literatürde çevikliğin kitlesel kişsiselleştirme için önemli olduğunu belirten çalışmalar bulunmaktadır (Mishra, Datta, \& Mahapatra, 2013, s. 441; Wang W. P., 2009, s. 3440; Barutcu, 2007, s. 588). Fakat bununla birlikte bu alanda yapılan ampirik çalışmaların oldukça sınırlı olduğu söylenebilir. Literatür bölümünde de belirtildiği gibi yapılan bu ampirik araştırmalar, bu iki değişken arasındaki neden sonuç ilişkisine değinmekten ziyade, çok kriterli karar verme teknikleriyle kitlesel kişiselleştirme için uygun çeviklik stratejisinin belirlenmesine odaklanmaktadırlar.

Araştırmanın dördüncü, beşinci ve altıncı hipotezleri tedarik zinciri entegrasyonunun kitlesel kişiselleştirme yeteneği üzerindeki etkisini incelemektedir. Araştırma sonuçlarına göre iç entegrasyonun kitlesel kişiselleştirme üzerindeki etkisi tespit edilememiştir. Bu bulgu diğer araştırmaların sonuçlarından farklılık göstermektedir (Lai, Zhang, Lee, \& Zhao, 2012, s. 453). Bununla birlikte, müşteri ve tedarikçi entegrasyonunun kitlesel kişiselleştirme yeteneği üzerinde pozitif ve anlamlı etkisi belirlenmiştir. Tedarikçi ve müşteri ile bilgi paylaşımı, işletmenin pazar, talep, hammadde ve bileşenler hakkında bilgi sahibi olmasına yardımcı olacaktır. Müşteri ve tedarikçilerin ürün tasarımına erken katılımı, etkili bir kişiselleştirme yapmayı kolaylaştıracaktır. Ayrıca tedarikçi ve müşterilerle kurulan ortaklıklar, işletmenin bazı kaynaklara daha kolay ulaşmasına imkân tanıyacaktır. İşletmeler, elde edilen bu kaynakları kullanarak daha etkin bir kişiselleştirme yapabilir ve ürünlerin fiyatı, kalitesi ve işlevselliği konusundaki kararlarını iyileştirebilirler. Ayrıca uzun vadeli bir iş birliğine dayalı olarak kurulan ilişkiler, bilginin tedarik zinciri boyunca serbestçe akmasını sağlayarak maliyeti, riski, çatışmaları ve bürokratik gecikmeleri azaltabilecektir. Bulgularımız, müşteri ve tedarikçi entegrasyonuyla işletmelerin kitlesel kişiselleştirme yeteneği kazanabileceklerini göstermektedir.

Kitlesel kişiselleştirme, günümüzde birçok işletme için kaçınılmaz olsa da aynı zamanda uygulanması zor olan bir faaliyettir. Dolayısıyla, bu kavramın gelişmesine katkı sağlayacak olan unsurları belirlemek, yöneticilere kitlesel kişiselleştirme arayışında yardımcı olacaktır. Dış entegrasyonun (tedarikçi ve müşteri) bu kavram üzerinde anlamlı bir etkisi olması nedeniyle, kitlesel kişiselleştirme yapmak isteyen işletmeler, TZ boyunca faaliyetlerini entegre etmek için çabalamalıdırlar. 


\subsection{Araştırmanın Kısıtları ve Gelecek Araştırmalar İçin Öneriler}

$\mathrm{Bu}$ araştırmadaki en önemli kısıt, örneklem büyüklüğünün nispeten küçük olmasıdır. Çalışmada 83 işletmeden veri toplanmıştır. PLS-YEM, küçük örneklemde etkili çalışabilse de daha büyük bir örneklem, çalışmanın genellenebilir olması adına önemlidir. İkinci kısıt, araştırmada her işletmeden tek bir yönetici ile iletişim kurularak veri temin edilmesidir. Ancak, üretim ve tedarik zinciri alanında yapılan çalışmalar, bu yaklaşımın yaygın bir biçimde kullanıldığını göstermektedir (Zhang, Zhao, Lyles, \& Guo, 2015, s. 1284). Bir diğer kısıt ise çalışmada çeviklik kavramının sadece operasyonel çeviklik açısından ele alınmasıdır. Gelecek araştırmalarda çevikliğin diğer boyutları (müşteri ve iş ortaklığı gibi) da incelenebilir. Son olarak, kitlesel kişiselleştirmeyle ilgili maddelerin ortalamalarına bakıldığında bu ölçekte yer alan tüm maddelerin ortalamanın biraz üstünde olduğu görülmektedir. Bu durum, işletmelerin belirli oranda kişiselleştirmeye yöneldiklerine fakat henüz yeterli olgunluğa ulaşmadıklarına işaret etmektedir. $\mathrm{Bu}$ nedenle gelecek çalışmalarda kitlesel kişiselleştirmenin önündeki engellerin araştırılması mümkündür.

Etik Beyan: Bu calssmada kullanulan veriler 2020 ynl öncesine ait olduğu için etik kurul izni ve zorunluluğu bulunmamaktadir. Aksi bir durumun tespiti halinde Sosyal Ekonomik. Araştırmalar Dergisinin biçbir sorumluluğu olmayip, tüm sorumluluk. çalsmanm yazarlarina aittir.

Yazar Katkı Beyanı: 1. Yazarm katkı oranı \%50, 2. Yazarn katkı oran ise \%50'dir.

Çıkar Beyanı: Yaz̧arlar herhangi bir çıkar çațşması olmadiğın beyan etmektedirler.

\section{KAYNAKÇA}

Akhtar, P., Khan, Z., Tarba, S., \& Jayawickrama, U. (2018). The internet of things, dynamic data and information processing capabilities, and operational agility. Technological Forecasting \& Social Change, 136, $307-$ 316.

Akkaya, B., \& Tabak, A. (2018). Örgütsel çeviklik ölçeğinin Türkçeye uyarlanması: Geçerlik ve güvenirlik çalışması. Isş ve Insan Dergisi, 5(2), 185-206.

Alfalla-Luque, R., Medina-Lopez, C., \& Dey, P. (2013). Supply chain integration framework using literature review. Production Planning \& Control, 24(8-9), 800-817.

Bagchi, P., Ha, B., Skjoett-Larsen, T., \& Soerensen, L. (2005). Supply chain integration: A European survey. The International Journal of Logistics Management, 16(2), 275-294.

Barutcu, S. (2007). Customized products: The integrating relationship marketing, agile manufacturing and supply chain management for mass customization. Ege Academic Review, 7(2), 573-593.

Beck, R., Pahlke, L., \& Vykoukal, J. (2016). Colocation as a hybrid ICT sourcing strategy to improve operational agility. The Data Base for Advances in Information Systems, 47(2), 9-35.

Cagliano, R., Caniato, F., \& Spina, G. (2006). The linkage between supply chain integration and manufacturing improvement programmes. International Journal of Operations \& Production Management, 26(3), 282-299.

Chaudhuri, A., Boer, H., \& Taran, Y. (2018). Supply chain integration, risk management and manufacturing flexibility. International Journal of Operations \& Production Management, 38(3), 690-712.

Çakar, F. (2020). Kısmi En Küçük Kareler Yapısal Eşitlik Modellemesi (PLS-SEM). Ankara: Gazi Kitabevi.

Da Silveira, G., Borenstein, D., \& Fogliatto, F. (2001). Mass customization: Literature review and research directions. International Journal Production Economics, 72, 1-13.

Devaraj, S., Krajewski, L., \& Wei, J. C. (2007). Impact of e-business technologies on operational performance: The role of production information integration in the supply chain. Journal of Operations Management, 25(6), 1199-1216.

Flynn, B. B., Huo, B., \& Zhao, X. (2010). The impact of supply chain integration on performance: A contingency and configuration approach. Journal of Operations Management, 28(1), 58-71. 
Fremdt, S., Beck, R., \& Weber, S. (2013). Does cloud computıng matter? An analysis of the cloud model software-as-a-service and its impact on operational agility. 46th Hawaii International Conference on System Sciences (s. 1025-1034). Wailea: HICSS.

Germain, R., \& Iyer, K. N. (2006). The interaction of internal and downstream integration and its association with performance. Journal of Business Logistics, 27(2), 29-52.

Henseler, J., Hubona, G., \& Ray, P. (2016). Using PLS path modeling in newt echnology research: Updated guidelines. Industrial Management \& Data Systems, 116(1), 2-20.

Huang, P. Y., Ouyang, T., Pan, S., \& Chou, T. C. (2012). The role of IT in achieving operational agility: A case study of Haier, China. International Journal of Information Management, 32, 294-298.

Huang, P. Y., Pan, S., \& Ouyang, T. (2014). Developing information processing capability for operational agility: Implications from a Chinese manufacturer. European Journal of Information Systems, 23(4), 462-480.

Jajja, M., Chatha, K., \& Farooq , S. (2018). Impact of supply chain risk on agility performance: Mediating role of supply chain integration. International Journal of Production Economics, 205, 118-138.

Kalaycı, Ş. (2008). SPSS Uygulamah Çok Değış̧eeli İstatistik Teknikleri. Ankara: Asil Yayın Dağıtım.

Kumar, G., \& Banerjee, R. N. (2012). Collaboration in supply chain: An assessment of hierarchical model using partial least squares (PLS). International Journal of Productivity and Performance Management, 61(8), 897-918.

Lai, F., Zhang, M., Lee, D., \& Zhao, X. (2012). The impact of supply chain integration on mass customization capability: An extended resource-based view. IEEE Transactions on Engineering Management, 59(3), 443-456.

Liao, K., Ma, Z., Yee Lee, J., \& Ke, K. (2011). Achieving mass customization through trust-driven information sharing: A supplier's perspective. Management Research Review, 34(5), 541-552.

Liu , G., Shah, R., \& Schroeder, R. (2006). Linking work design to mass customization: A sociotechnical systems perspective. Decision Sciences, 37(4), 519-45.

Liu, G., \& Deitz, G. (2011). Linking supply chain management with mass customization capability. International Journal of Physical Distribution \& Logistics Management, 41(7), 668-683.

Liu, G., Zhang, W., \& Guo, C. (2018). Impacts of supply chain planning and integration on mass customization. Journal of Manufacturing Technology Management, 29(3), 608-628.

Liu, S., Chan, F., \& Yang, J. (2018). Understanding the effect of cloud computing on organizational agility: An empirical examination. International Journal of Information Management, 43, 98-111.

Malhotra, N., Kim, S., \& Patil, A. (2006). Common method variance in IS research: A comparison of alternative approaches and a reanalysis of past research. Management Science, 52(12), 1865-1883.

Merschmann, U., \& Thonemann, U. W. (2011). Supply chain flexibility, uncertainty and firm performance: An empirical analysis of German manufacturing firms. International Journal of Production Economics, 130(1), 4353.

Mishra, S., Datta, S., \& Mahapatra, S. (2013). Grey-based and fuzzy TOPSIS decision-making approach for agility evaluation of mass customization systems. Benchmarking: An International Journal, 20(4), 440-462.

Munir, M., Jajja, M. S., Chatha, K. A., \& Farooq, S. (2020). Supply chain risk management and operational performance: The enabling role of supply chain integration. International Journal of Production Economics, 227, $1-14$.

Podsakoff, P., Mackenzie, S., Podsakoff, N., \& Lee, J. (2003). Common method biases in behavioral research: A critical review of the literature and recommended remedies. Journal of Applied Psychology, 88(5), 879-903.

Prajogo, D., \& Olhager, J. (2012). Supply chain integration and performance: The effects of long-term relationships, information technology and sharing, and logistics integration. International journal of Production Economics, 135, 514-522. 
Rai, A., Patnayakuni, R., \& Seth, N. (2006). Firm performance impacts of digitally enabled supply chain integration capabilities. MIS Quarterly, 30(2), 225-246.

Ramirez, M., Roman, I., Ramos, E., \& Patrucco, A. (2021). The value of supply chain integration in the Latin American agri-food industry: Trust, commitment and performance outcomes. The International Journal of Logistics Management, 32(1), 284-304.

Romano, P. (2003). Co-ordination and integration mechanisms to manage logistics processes across supply networks. Journal of Purchasing \& Supply Management, 9, 119-134.

Sandrin, E., Trentin, A., \& Forza, C. (2018). Leveraging high-involvement practices to develop mass customization capability: A contingent configurational perspective. International Journal of Production Economics, $196,335-345$.

Sayan, Z. (2018). Lojistik, pazarlama ve üretim arasındaki içsel entegrasyonun, tedarik zincirinin süre odaklı performansına etkisi algısının ölçülmesi: Güven ve bilgi teknolojilerinin aracı değişken rolü. (Yayınlanmamış Doktora Tezi). Ankara: Hacettepe Üniversitesi Sosyal Bilimler Enstitüsü.

Schoenherr, T., \& Swink, M. (2012). Revisiting the arcs of integration: Cross-validations and extensions. Journal of Operation Management, 30(1-2), 99-115.

Selladurai, R. (2004). Mass customization in operations management: Oxymoron or reality? Omega, 32(4), 295-300.

Shukor, A., Newaz, M., Rahman, M., \& Taha, A. (2020). Supply chain integration and its impact on supply chain agility and organizational flexibility in manufacturing firms. International Journal of Emerging. doi:10.1108/IJOEM-04-2020-0418

Stonebraker, P. W., \& Liao, J. (2004). Environmental turbulence, strategic orientation. International Journal of Operations \& Production Management, 24(10), 1037-1054.

Sundram, V. P., Bahrin, A. S., Munir, Z. B., \& Zolait, A. H. (2018). The effect of supply chain information management and information system infrastructure. Journal of Enterprise Information Management, 31(5), 751770.

Tu, Q., Vonderembse, M., \& Ragu-Nathan, T. (2001). The impact of time-based manufacturing practices on mass customization and value to customer. Journal of Operations Management, 19(2), 201-217.

Wang, W. P. (2009). Toward developing agility evaluation of mass customization systems using 2-tuple linguistic computing. Expert Systems with Applications, 36, 3439-3447.

Wang, Z., \& Zhang, M. (2020). Linking product modularity to supply chain integration and flexibility. Production Planning \& Control, 31(14), 1149-1163.

Xu, D., Huo, B., \& Sun, L. (2014). Relationships between intra-organizational resources, supply chain integration and business performance: An extended resource-based view. Industrial Management \& Data Systems, 114(8), 1186-1206.

Yıldız, B., \& Çetindaş, A. (2020). Tedarik zinciri entegrasyonunun firma performansı üzerindeki etkisinde tedarik zinciri esnekliği ve tedarik zinciri çevikliğinin aracı rolü. Verimlilik Dergisi, 3, 175-199.

Yu, Y., Huo, B., \& Zhang, Z. (2021). Impact of information technology on supply chain integration and company performance: Evidence from cross-border e-commerce companies in China. Journal of Enterprise Information Management, 34(1), 460-489.

Yüksel, B. (1999). İşletme-müşteri ilişkilerini kişisel boyuta indirgemede kitlesel kişiselleştirme (mass customization) stratejisinin rolü. Dumlupinar Üniversitesi Sosyal Bilimler Dergisi, 3, 207-224.

Zhang, M., Zhao, X., \& Qi, Y. (2014). The effects of organizational flatness, coordination, and product modularity on mass customization capability. International Journal of Production Economics, 158, 145-155.

Zhang, M., Zhao, X., Lyles, M., \& Guo, H. (2015). Absorptive capacity and mass customization capability. International Journal of Operations \& Production Management, 35(9), 1275-1294. 


\section{EKLER}

\section{Ek 1: Ölçek Maddeleri}

$1=$ kesinlikle katılmiyorum, $2=$ katılmıyorum, $3=$ kararsızım, $4=$ katıliyorum, $5=$ kesinlikle katıliyorum

\section{Kitlesel Kişiselleştirme Yeteneği}

1- Büyük ölçekli ürün özelleştirmesinde oldukça yetkiniz.

2- Maliyetleri artırmadan kolaylıkla ürün çeşitliliğini artırabiliriz.

3- Yüksek hacmi korurken ürünleri özelleştirebiliriz.

4- Kaliteden ödün vermeksizin ürün çeşitliliğini artırabiliriz.

5-Süreç tasarımımızı maliyetleri önemli ölçüde artırmaksızın müşteri talebine uygun olarak düzenleyebiliriz.

6-Ürün tasarımımızı maliyetleri önemli ölçüde artırmaksızın müşteri talebine uygun olarak düzenleyebiliriz.

\section{Operasyonel çeviklik}

1-Pazar değişikliklerine oldukça güvenilir bir şekilde cevap verebiliriz.

2- Pazar değişikliklerine uyum sağlamaya yönelik tekliflerimizde/faaliyetlerimizde gerekli esnekliğe sahibiz

3-Tekliflerimizi/ faaliyetlerimizi, pazar değişikliklerine uyum sağlamak için etkin bir şekilde yeniden tasarları.

4. Pazar firsatlarını oldukça hızlı bir şekilde değerlendirebiliriz.

\section{Müşteri Entegrasyonu}

1- Müşterilerimiz ile sürekli olarak yakın temas halindeyiz.

2- Müşterilerimiz ürün tasarım süreçlerimize aktif olarak katılmaktadırlar.

3-Müşterilerimiz kalite iyileştirme çabalarına bizi dâhil etmektedirler.

4-Müşterilerimizle ortak gibi çalışırız.

İç Entegrasyon

1-İşletmemizdeki fonksiyonlar iyi entegre edilmiştir.

2-İşletmemizin fonksiyonları icraatları koordine eder.

3-Üst yönetimimiz, fonksiyonlar arası iyi ilişkilerin önemini vurgular.

4-Yönetim tüm önemli kararlarda birlikte iyi bir şekilde çalışır.

\section{Tedarikçi Entegrasyonu}

1-Tedarikçilerle iş birlikçi ilişkiler sürdürürüz.

2-Kalite konuları ve tasarım değişiklikleri hakkında tedarikçiler ile yakın iletişim sürdürürüz.

3-Ana tedarikçilerimiz ürün geliştirme projelerimiz için veri sağlar.

4-Tedarikçiler ile uzun süreli ilişkiler kurmak için çabalarız. 